\title{
Carbonate system parameters of an algal-dominated reef along West Maui
}

\author{
Nancy G. Prouty ${ }^{1}$, Kimberly K. Yates ${ }^{2}$, Nathan Smiley ${ }^{2}$, Chris Gallagher ${ }^{3}$, Olivia Cheriton ${ }^{1}$, and Curt D. Storlazzi ${ }^{1}$ \\ ${ }^{1}$ U.S. Geological Survey, Coastal and Marine Geology, Pacific Coastal and Marine Science Center, \\ Santa Cruz, CA 95060, USA \\ ${ }^{2}$ U.S. Geological Survey, Coastal and Marine Geology, St. Petersburg Coastal and Marine Science Center, \\ 600 4th Street South, St. Petersburg, FL 33701, USA \\ ${ }^{3}$ University of California, Santa Cruz, Santa Cruz, CA 95060, USA
}

Correspondence: Nancy G. Prouty (nprouty@usgs.gov)

Received: 18 January 2018 - Discussion started: 23 January 2018

Revised: 22 March 2018 - Accepted: 22 March 2018 - Published: 23 April 2018

\begin{abstract}
Constraining coral reef metabolism and carbon chemistry dynamics are fundamental for understanding and predicting reef vulnerability to rising coastal $\mathrm{CO}_{2}$ concentrations and decreasing seawater $\mathrm{pH}$. However, few studies exist along reefs occupying densely inhabited shorelines with known input from land-based sources of pollution. The shallow coral reefs off Kahekili, West Maui, are exposed to nutrient-enriched, low-pH submarine groundwater discharge (SGD) and are particularly vulnerable to the compounding stressors from land-based sources of pollution and lower seawater $\mathrm{pH}$. To constrain the carbonate chemistry system, nutrients and carbonate chemistry were measured along the Kahekili reef flat every $4 \mathrm{~h}$ over a 6-day sampling period in March 2016. Abiotic process - primarily SGD fluxes - controlled the carbonate chemistry adjacent to the primary SGD vent site, with nutrient-laden freshwater decreasing $\mathrm{pH}$ levels and favoring undersaturated aragonite saturation $\left(\Omega_{\mathrm{arag}}\right)$ conditions. In contrast, diurnal variability in the carbonate chemistry at other sites along the reef flat was driven by reef community metabolism. Superimposed on the diurnal signal was a transition during the second sampling period to a surplus of total alkalinity (TA) and dissolved inorganic carbon (DIC) compared to ocean endmember TA and DIC measurements. A shift from positive net community production and positive net community calcification to negative net community production and negative net community calcification was identified. This transition occurred during a period of increased SGD-driven nutrient loading, lower wave height, and reduced current speeds. This detailed study of carbon chem-
\end{abstract}

istry dynamics highlights the need to incorporate local effects of nearshore oceanographic processes into predictions of coral reef vulnerability and resilience.

\section{Introduction}

Coral reefs provide critical shoreline protection and important ecosystem services, such as marine habitat, and support local economies through tourism, fishing, and recreation (Hughes et al., 2003; Ferrario et al., 2014). However, coral reefs are being threatened by global climate change processes, such as increasing temperatures, sea-level rise, and ocean acidification (OA), caused by uptake of atmospheric carbon dioxide into the ocean (Orr et al., 2005). These effects are often compounded by local stressors such as over-fishing, sedimentation, land-based sources of pollution, and coastal acidification (Knowlton and Jackson, 2008) that can result from freshwater inflow, eutrophication, and/or coastal upwelling. These stressors can lead to a decrease in reef health by removing grazing fish, decreasing calcification rates, and increasing nutrient and contaminant concentrations, thereby shifting the balance between reef accretion and erosion. However, isolating the effects of these stressors is difficult without establishing the biological and physical controls on community calcification and production. This is particularly challenging for coral reefs adjacent to densely inhabited shorelines, where freshwater fluxes can deliver excess nutrients. In turn, this can lead to coastal acidification 
caused by eutrophication and enhanced respiratory processes that release $\mathrm{CO}_{2}$ and increase coastal water acidity (e.g., Cai et al., 2011; Strong et al., 2014), outbreaks of harmful algal blooms (Anderson et al., 2002), and decreased coral abundance and diversity (Fabricius, 2005; Lapointe et al., 2005). In many cases, eutrophication can alter ecosystem function and structure by shifting reefs from coral to algae dominated (Howarth et al., 2000; Andrefouet et al., 2002; Hughes et al., 2007). Changes in community structure can have profound impacts on coral reef metabolism and reef carbon chemistry dynamics (e.g., Page et al., 2017), which are ultimately linked to reef health and the ability to predict future responses to rising $p \mathrm{CO}_{2}$ levels (Andersson and Gledhill, 2013). Understanding the local drivers of ecosystem function and reef community metabolism is critical for gauging the susceptibility of the reef ecosystem to future changes in ocean chemistry.

Numerous efforts have been conducted along West Maui, Hawaii, USA, to characterize and quantify submarine groundwater discharge (SGD) and associated nutrient input (Dailer et al., 2010, 2012; Glenn et al., 2013; Swarzenski et al., 2013, 2016; Silbiger et al., 2017), which may influence reef metabolism and community composition by changing coastal water quality. Building upon these studies, we present a comprehensive study to characterize the carbonate system parameters from the reefs in this area. The carbonate chemistry system is sensitive to changes in photosynthesis, respiration, calcification, and calcium carbonate $\left(\mathrm{CaCO}_{3}\right)$ dissolution, and can be characterized by measuring total alkalinity (TA), dissolved inorganic carbon (DIC), $\mathrm{pH}, p \mathrm{CO}_{2}$, nutrients, salinity, and temperature. Analysis of these parameters yields valuable information on ratios of net community calcification and production, and can be used to identify biological and physical drivers of reef health and ecosystem function (Silverman et al., 2007; Shamberger et al., 2011; Lantz et al., 2014; Albright et al., 2015; Muehllehner et al., 2016; DeCarlo et al., 2017; Richardson et al., 2017; Cyronak et al., 2018). This is particularly important given growing concern that coastal and ocean acidification may shift reef ecosystems from calcification to dissolution by the middle to end of the century (Silverman et al., 2009; Andersson and Gledhill, 2013) with an overall reduction in calcification rates and increase in dissolution rates (Shamberger et al., 2011; Shaw et al., 2012; Bernstein et al., 2016) that can contribute to reef collapse (Yates et al., 2017).

The health of many of Maui's coral reefs has been declining rapidly (Rodgers et al., 2015), with recent coral bleaching events leading to increased coral mortality (Sparks et al., 2016). The decline in coral cover along the shallow coral reef at Kahekili has been observed for decades (Wiltse, 1996; Ross et al., 2012), along with a history of macro-algal blooms (Smith et al., 2005). The shift in benthic cover from abundant corals to turf or macro-algae (primarily Ulva fasciata) and increased rates of coral bioerosion have been linked to input of nutrient-rich water via wastewater injection wells
(Dailer et al., 2010, 2012; Prouty et al., 2017a). Treated wastewater is injected through these wells into groundwater that flows toward the coast where it emerges on the reef through a network of small seeps and vents (Glenn et al., 2013; Swarzenski et al., 2016). Changes in coastal water quality observed off West Maui can impact the balance of production of $\mathrm{CaCO}_{3}$ skeletons by calcifying algae and animals on the reef, cementation of sand and rubble, and $\mathrm{CaCO}_{3}$ breakdown and removal that occurs through bioerosion, dissolution, and offshore transport. Here, a high-resolution seawater sampling study was conducted to constrain the carbonate chemistry system and evaluate the biological and physical processes altering reef health along the shallow coral reef at Kahekili in Kaanapali, West Maui, Hawaii, USA (Fig. 1). This study characterizes the diurnal and multi-day variability of coral reef carbonate chemistry along a tropical fringing reef adjacent to a densely inhabited shoreline with known input from land-based sources of pollution, and identifies the controls on carbon metabolism. Ultimately, understanding carbonate system dynamics is essential for managing compounding effects from local stressors.

\section{Methods}

\subsection{Study site}

The benthic habitat along the shallow reef at Kahekili in Kanapali, West Maui (Fig. 1), consists of aggregate reef, patch reef, pavement, reef rubble, and spur and groove (Cochran et al., 2014), with persistent current flow to the south (Storlazzi and Jaffe, 2008). Only $51 \%$ of the hardbottom at Kahekili is covered with at least $10 \%$ live coral, with the remaining hardbottom consisting of aggregate reef, spur and groove, patch reefs, pavement, and reef rubble (Cochran et al., 2014). The shallow fore reef experiences algae blooms in response to inputs of nutrient-rich water via wastewater injection wells (Dailer et al., 2010, 2012). Groundwater inputs occur from both natural sources (rainfall and natural infiltration) and from artificial recharge (irrigation and anthropogenic wastewater). The inland Wailuku Basalt, consisting of a band of unconsolidated sediment along the coast and a small outcrop of Lahaina Volcanics, dominates the geology of the area surrounding the study site, controlling the flow of groundwater (Langenheim and Clague, 1987; Gingerich and Engott, 2012). Mean annual precipitation rates are up to $900 \mathrm{~cm} \mathrm{yr}^{-1}$ (Giambelluca et al., 2013), with natural recharge the greatest in the interior mountains.

\subsection{Field sampling}

Two intensive sampling periods were carried out during the 6-day period from 16 to 24 March 2016 along the reef flat with live coral cover. Seawater nutrients and carbonate chemistry variables were collected every $4 \mathrm{~h}$ during each sampling period from the primary vent site and in adjacent coastal 


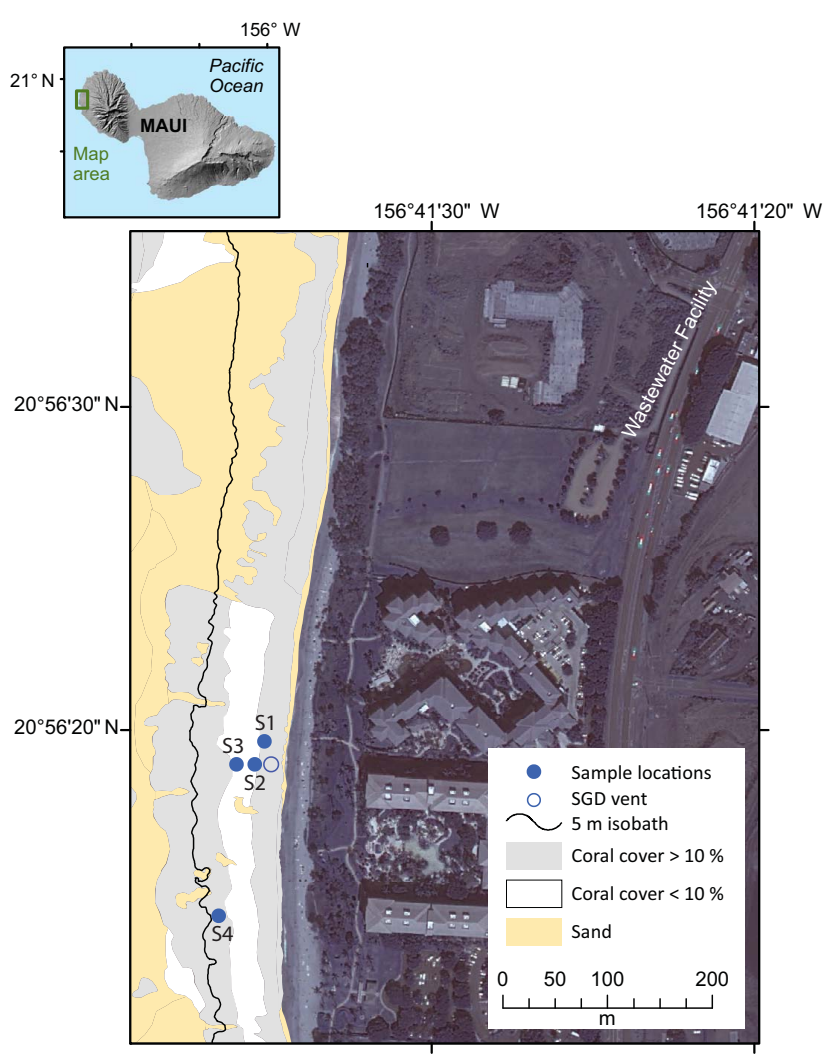

Figure 1. Location map of the island of Maui, Hawaii, USA, and the study area along West Maui. Bathymetric map ( $5 \mathrm{~m}$ contours) of study area showing seawater sampling locations (blue closed circle) along Kahekili Beach Park, and the primary seep site (blue open circle) superimposed on distribution of percent coral cover versus sand.

waters along the shallow reef at Kahekili (Fig. 1). The first sampling period was from 15:00 HST on 16 March 2016 to 15:00 HST on 19 March 2016, and the second sampling period was from 15:00 HST on 21 March 2016 to 11:00 HST on 24 March 2016 (all reported times in local time). There were five sampling sites: two shallow $(<1.5 \mathrm{~m})$ sites ( $\mathrm{S} 1$ and $\mathrm{S} 2)$ located approximately $10 \mathrm{~m}$ offshore, two deeper $(5 \mathrm{~m})$ sites (S3 and S4) located approximately $115 \mathrm{~m}$ offshore, and a shallow site located approximately $20 \mathrm{~m}$ offshore and within $0.25 \mathrm{~m}$ of an active SGD vent (vent site; $<1.5 \mathrm{~m}$ ) (Glenn et al., 2013; Swarzenski et al., 2016). Sampling tubes (ranging from approximately 100 to $200 \mathrm{~m}$ in length) were installed at each site by affixing the tube to a concrete block located approximately $20 \mathrm{~cm}$ above the seafloor or by attaching the tubing directly to dead reef structure using zip ties. Tube intakes were fitted with a stainless-steel screen cap to prevent uptake of large particulates. The remaining length of each tube was positioned along the seafloor to the adjacent beach by weighting the tube with a $1 \mathrm{~m}$ piece of chain or by weaving the tube through dead reef structure approximately every $20 \mathrm{~m}$. The tube outflow ends were labeled for each sampling site, bundled in a common location, and located above the high water line on the beach for sampling access. A peristaltic pump was used to pump seawater from the seafloor. Sampling tubes were flushed for a minimum of $20 \mathrm{~min}$ to remove residual seawater before collecting data and water samples. Sampling tubes were inspected upon extraction and no significant algal growth was observed. Temperature, salinity, and dissolved oxygen of water samples were measured using a YSI ProPlus multimeter that was calibrated daily with an accuracy of $\pm 0.2^{\circ} \mathrm{C}, \pm 0.1 \mathrm{psu}$, and $\pm 0.2 \mathrm{mg} \mathrm{L}^{-1}$, respectively. However, due to temperature change during water transit time within the sampling tube, in situ temperatures were also recorded from Solonist conductivity-temperaturedepth (CTD) divers installed at the intake of each sampling tube. An upward-looking $2 \mathrm{MHz}$ Nortek Aquadopp acoustic Doppler profiler (ADP) was deployed at the southern deeper site (S4). The ADP sampled waves at $2 \mathrm{~Hz}$ for 17 min every hour and currents at $1 \mathrm{~Hz}$ every $10 \mathrm{~min}$ in $1 \mathrm{~m}$ vertical bins from $1 \mathrm{~m}$ above the seabed up to the ocean surface.

\subsection{Seawater analyses}

Samples for dissolved nutrients $\left(\mathrm{NH}_{4}^{+}, \mathrm{Si}, \mathrm{PO}_{4}^{3-}\right.$, and $\left[\mathrm{NO}_{3}^{-}+\mathrm{NO}_{2}^{-}\right]$) were collected in duplicate by filtering water with an in-line $0.45 \mu \mathrm{m}$ cellulose nitrate filter and $0.20 \mu \mathrm{m}$ polyethersulfone syringe filter, and were kept frozen until analysis. Nutrients were analyzed at the Woods Hole Oceanographic Institution's nutrient laboratory and University of California at Santa Barbara's Marine Science Institute Analytical Laboratory via flow injection analysis for $\mathrm{NH}_{4}^{+}, \mathrm{Si}, \mathrm{PO}_{4}^{3-}$, and $\left[\mathrm{NO}_{3}^{-}+\mathrm{NO}_{2}^{-}\right]$, with precisions of $0.6-$ $3.0,0.6-0.8,0.9-1.3$, and $0.3-1.0 \%$ relative standard deviations, respectively. Select samples were collected and analyzed for nitrate isotope $\left(\delta^{15} \mathrm{~N}\right.$ and $\left.\delta^{18} \mathrm{O}\right)$ analyses at the University of California at Santa Cruz using the chemical reduction method (McIlvin and Altabet, 2005; Ryabenko et al., 2009) and University of California at Davis' Stable Isotope Facilities using the denitrifier method (Sigman et al., 2001). The isotope analysis was conducted using a Thermo Finnigan MAT 252 coupled with a GasBench II interface; isotope values are presented in per mil (\%o) with respect to AIR for $\delta^{15} \mathrm{~N}$ and Vienna Standard Mean Ocean Water (VSMOW) for $\delta^{18} \mathrm{O}$ with a precision of $0.3-0.4$ and $0.5-0.6 \%$ for $\delta^{15} \mathrm{~N}$ nitrate and $\delta^{18} \mathrm{O}$-nitrate, respectively.

Seawater samples for determining carbonate chemistry variables ( $\mathrm{pH}$ on the total scale, TA, and DIC) were collected from the five sampling sites using a peristaltic pump and pressure filtering seawater through a $0.45 \mu \mathrm{m}$ filter. Samples for $\mathrm{pH}(0.007 \pm 0.017)$ were filtered into $30 \mathrm{~mL}$ optical glass cells and analyzed within $1 \mathrm{~h}$ of collection using spectrophotometric methods (Zhang and Byrne, 1996), an Ocean Optics USB2000 spectrometer, and thymol blue indicator dye. Samples for TA and DIC were filtered into $300 \mathrm{~mL}$ borosilicate glass bottles, preserved by adding $100 \mu \mathrm{L}$ saturated $\mathrm{HgCl}_{2}$ solution, and pressure sealed with ground glass stop- 
pers coated with Apiezon grease. TA samples were analyzed using spectrophotometric methods of Yao and Byrne (1998) with an Ocean Optics USB2000 spectrometer and bromocresol purple indicator dye. DIC samples were analyzed using a UIC carbon coulometer model CM5014 and CM5130 acidification module fitted with a sulfide scrubber, and methods of Dickson et al. (2007). In situ temperatures recorded from Solonist CTD divers were reported and used to temperature correct $\mathrm{pH}$ and perform $\mathrm{CO} 2 \mathrm{SYS}$ calculations as described below.

Certified reference materials (CRMs) for TA and DIC analyses were from the Marine Physical Laboratory of Scripps Institution of Oceanography (Dickson et al., 2007). TA and DIC sample accuracy were within $0.56 \pm 0.55$ and $1.50 \pm 1.17 \mu \mathrm{mol} \mathrm{kg}^{-1}$ of certified reference material, respectively. Precision for TA based on replicate sample analyses was $0.76 \pm 0.83 \mu \mathrm{mol} \mathrm{kg}{ }^{-1}$. Precision for DIC based on replicate sample analyses was $1.9 \pm 1.5 \mu \mathrm{mol} \mathrm{kg}{ }^{-1}$. The full seawater $\mathrm{CO}_{2}$ system was calculated with measured salinity, temperature, nutrients (phosphate and silicate), TA, DIC, and $\mathrm{pH}$ data using an Excel Workbook Macro translation of the original CO2SYS program (Pierrot et al., 2006). Given the enriched nutrient setting of the study site, TA values were nutrient corrected in CO2SYS (Dickson, 1981). The aragonite saturation state $\left(\Omega_{\text {arag }}\right)$ and $p \mathrm{CO}_{2}$ are reported based on DIC-pH pairs, with dissociation constants $K_{1}$ and $K_{2}$ from Mehrbach et al. (1973) refit by Dickson and Millero (1987) and $\mathrm{KSO}_{4}$ from Dickson (1990). The TA and DIC values were normalized to salinity (by multiplying by a factor of $35 / S$, where $S$ is the measured salinity value) to account for variations in TA and DIC along the reef flat driven by evaporation and/or precipitation (Friis et al., 2003) and are reported as $n \mathrm{TA}$ and $n \mathrm{DIC}$ as previously established in reef geochemical surveys (e.g., Suzuki and Kawahata, 2003; Yates et al., 2014; Muehllehner et al., 2016) where TA and DIC exhibit non-conservative behavior with respect to salinity. However, at the vent site, the TA and DIC data were not normalized to salinity given the contribution of TA and DIC from SGD.

\subsection{Statistical analysis}

Slope of salinity normalized total alkalinity ( $n \mathrm{TA}$ ) to salinity normalized dissolved inorganic carbon (DIC), net community calcification to net community production ratio $(\mathrm{NCC}: \mathrm{NCP}=2 \Delta \mathrm{DIC} /(\Delta \mathrm{TA}-1)$ ) (Suzuki and Kawahata, 2003), correlation coefficients $\left(r^{2}\right)$, analysis of variance (ANOVA), and standard error of difference $\left(\mathrm{SE}_{\mathrm{dif}}\right)$ were calculated in Excel v. 14.7.6. Histogram plots and cubic spline fits were made in KaleidaGraph 4.1.3.

\section{Results}

\subsection{Submarine groundwater endmember}

The magnitude of change and absolute values in the carbonate chemistry, nutrients, and salinity were greatest at the primary vent site relative to the four sites along the reef. The salinity ranged from 10.64 to 36.72 over the 6-day period (Fig. 2a), with the most dramatic decrease in salinity on 22 March 2016 when salinity decreased from 32.45 to 12.47 within $4 \mathrm{~h}$. The reduction in salinity was sustained over a $32 \mathrm{~h}$ period. A rapid change was also observed in the $\mathrm{pH}$, DO, TA, DIC, and nutrient concentrations (Fig. 2). For example, nitrate concentrations at the vent site ranged from 0.45 to over $70 \mu \mathrm{mol} \mathrm{L}^{-1}$, with an average nitrate concentration of $117 \pm 0.09 \mu \mathrm{mol} \mathrm{L}^{-1}$ measured directly from the discharging seep water. The $\Omega_{\text {arag }}$ values decreased to less than 1 and $p \mathrm{CO}_{2}$ values increased to $2000 \mu \mathrm{atm}$ when salinity values dropped to less than 15 (Fig. 2d). No diurnal pattern was detected in the seawater carbonate chemistry at this site. Instead, these results are consistent with earlier work documenting lower-pH, nutrient-enriched freshwater endmember values tightly coupled to SGD (Swarzenski et al., 2012, 2016; Glenn et al., 2013).

\subsection{Reef flat}

In contrast to the vent site, the overall magnitude of carbonate chemistry variation at the other four sites along the reef flat was lower, and the signal was coherent among these sites. This coherency is captured in the $\mathrm{pH}$ time series (Fig. 3b), where the $\mathrm{pH}$ data from the four sites were significantly $(p<0.05)$ positively correlated with each other (with Pearson correlation coefficient $r=0.5$ ). The lowest salinity value along the reef flat was 33.51 , indicating minimal freshwater influence on reef flat salinity. As a result, the carbonate system parameters measured along the reef were non-linear with respect to salinity (Fig. S1 in the Supplement); instead, a diurnal pattern dominated the signal (Fig. 3). Lowest $\mathrm{pH}$ values occurred around midnight (23:00); and highest $\mathrm{pH}$ values occurred in the afternoon $(\sim 14: 00-15: 00)$. This diurnal pattern was also apparent in the DIC data, with lowest values in the afternoon and increasing around midnight, with a cubic spline fit (Press et al., 1988) highlighting diurnal cycle from all four sites along the reef flat. Likewise, the diurnal signal was identifiable in the $\Omega_{\text {arag }}$ and $p \mathrm{CO}_{2}$ time series, with $\Omega_{\text {arag }}$ values increasing and $p \mathrm{CO}_{2}$ decreasing during the midday hours (Fig. 3). The diurnal signal in the $n \mathrm{TA}$ time series was similar to the signal for $n \mathrm{DIC}$. At the shallow $(<5 \mathrm{~m})$ sites, $\mathrm{pH}$ and DO covaried $\left(r^{2}=0.43-\right.$ $0.87 ; p<0.001)$. The range in $\mathrm{pH}$ and $\Omega_{\text {arag }}$ was largest at the shallow sites; however, the average values were similar along the reef, 3.02 to 3.06 and 8.00 to 8.01 , respectively, and were elevated relative to the average values recorded at the vent site, $7.85 \pm 0.17$ and $2.28 \pm 0.81$ for $\mathrm{pH}$ and $\Omega_{\mathrm{arag}}$, 

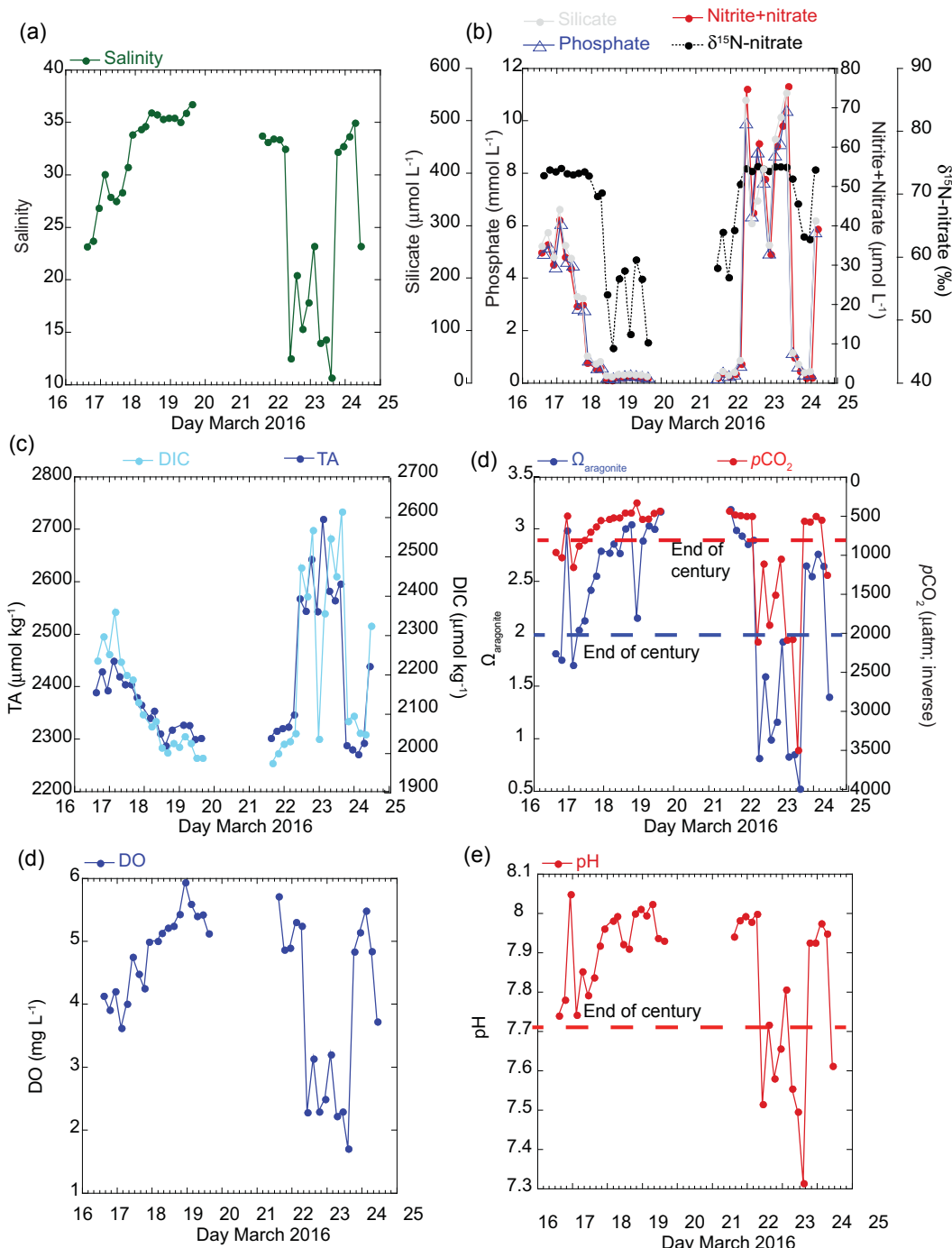

(e)

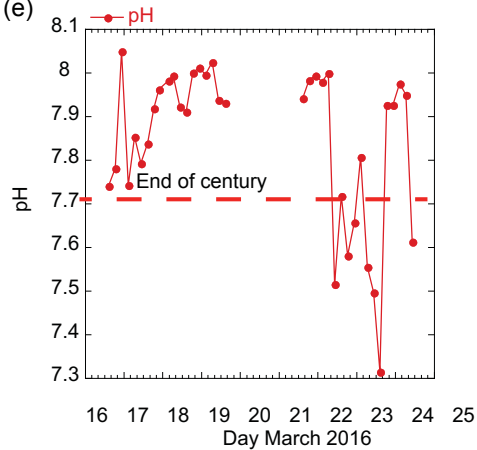

Figure 2. Results of time series of seawater chemistry variables over a 6-day period collected from the vent site located on the nearshore reef every $4 \mathrm{~h}$. (a) Salinity, (b) dissolved nutrient (nitrate plus nitrite, phosphate, and silicate) concentrations $(\mu \mathrm{mol} \mathrm{L}-1)$, and nitrate stable nitrogen isotopes $\left(\delta^{15} \mathrm{~N}\right.$-nitrate; $\%$ ), (c) total alkalinity (TA) and dissolved inorganic carbon (DIC) $\left(\mu \mathrm{mol} \mathrm{kg}{ }^{-1}\right),(\mathbf{d})$ calculated carbonate parameters for aragonite saturation state $\left(\Omega_{\mathrm{arag}}\right)$, and $\mathrm{pCO}_{2}$ ( $\mu \mathrm{atm}$; inverted) based on DIC-pH pairwise and measured salinity, temperature, nutrient (phosphate and silicate) data, (e) dissolved oxygen (DO; $\mathrm{mg} \mathrm{L}^{-1}$ ), and (f) temperature-corrected $\mathrm{pH}$ (total scale). End-of-century projections are according to IPCC-AR5 RCP8.5 "business as usual” scenario for pH (reduction by 0.4 units), $\Omega_{\text {arag }}(2.0$; blue dashed), and $p \mathrm{CO}_{2}(750 \mu \mathrm{atm} ;$ red dashed $)$.

respectively (Prouty et al., 2017b). No diurnal pattern was observed for the nutrient data; however, there was an offshore gradient in nutrient concentrations with enriched nutrients at the shallow sites compared to the deeper sites. Nutrient concentrations $\left(\mathrm{Si}, \mathrm{PO}_{4}^{3-}\right.$, and $\mathrm{NO}_{3}^{-}$) from the two shallow sites were statistically greater than the two deeper sites according to pairwise multi-comparison one-way ANOVA with a post hoc Tukey HSD (honest significant difference) $(p>0.05)$. For example, average nitrate concentrations at the two shallow sites were $0.71 \pm 0.35$ and $0.41 \pm 0.18$ compared to $0.17 \pm 0.10$ and $0.19 \pm 0.11 \mu \mathrm{mol} \mathrm{L}^{-1}$ at the deeper sites. Deficits and surpluses of $n \mathrm{TA}$ and $n \mathrm{DIC}$, with respect to open-ocean conditions, were calculated as $\Delta n \mathrm{TA}$ and $\Delta n$ DIC using values from station HOT (Dore et al., 2009), located approximately $250 \mathrm{~km}$ offshore as reported from 1988 to 2015 (http://hahana.soest.hawaii.edu/hot/products/ products.html). The $\Delta n \mathrm{TA}$ values ranged from -332 to 85 , and $\Delta n$ DIC ranged from -171 to $141 \mu \mathrm{mol} \mathrm{kg}-1$. The standard error of difference ( $\mathrm{SE}_{\mathrm{dif}}$ ) was calculated for $\Delta n \mathrm{TA}$ and $\Delta n$ DIC values to evaluate whether the deficits and surpluses of $n \mathrm{TA}$ and $n \mathrm{DIC}$ were significant. Histogram plots reveal statistical ( $p=0.05$; critical $t$ value of $1.68 ; \mathrm{df}=37)$ deficits and surpluses as well as differences between the first and second halves of the sampling period (Fig. 4). Results show 

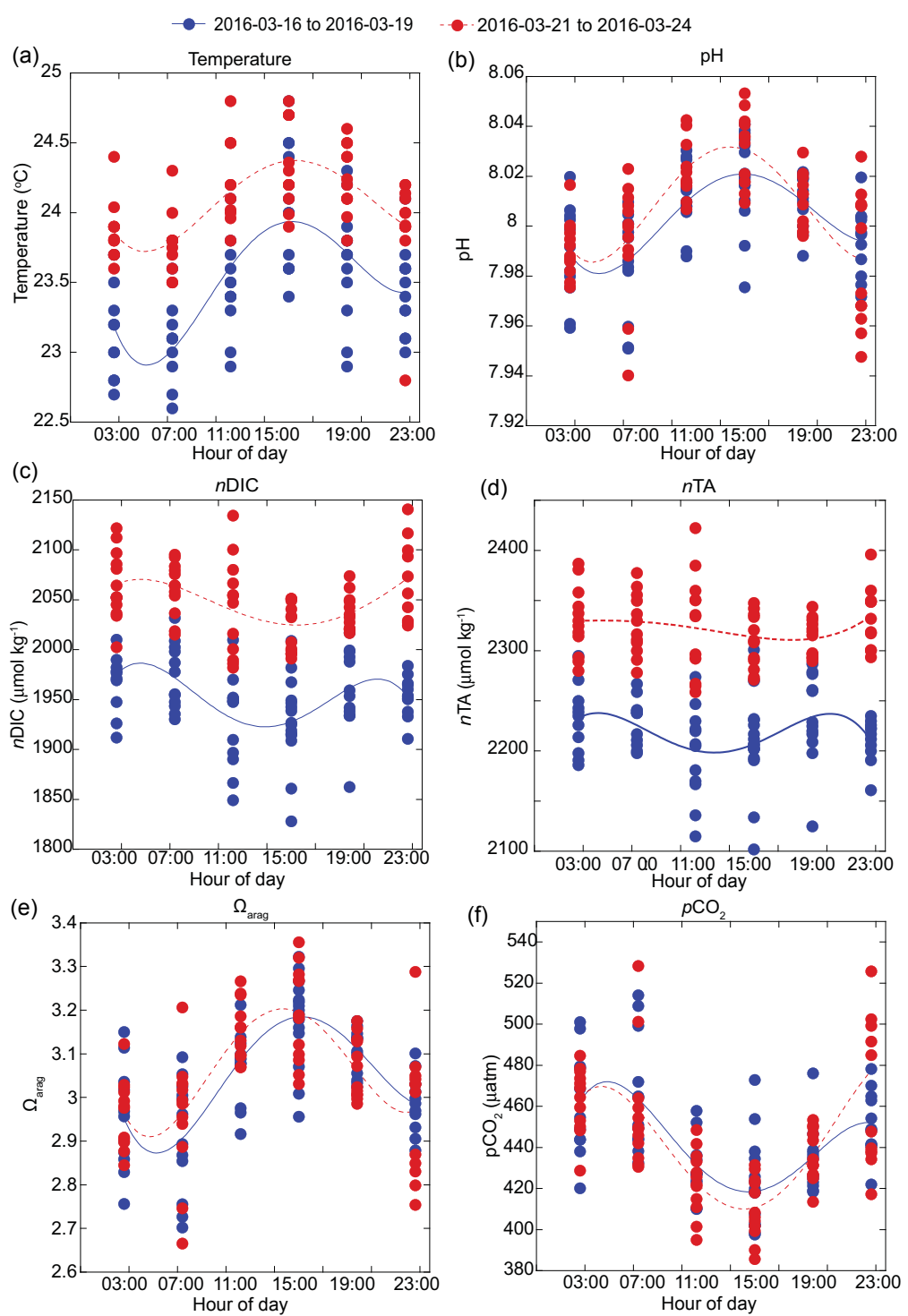

Figure 3. Carbonate chemistry parameters and sea surface temperature (SST) composite from S1, S2, S3, and S4 along the shallow reef flat of Kahekili, Maui, and cubic spline fits highlighting diurnal cycle for the first (16 to 19 March 2016; blue solid line) and second (21 to 24 March 2016; red dashed line) sampling periods for (a) temperature, (b) $\mathrm{pH},(\mathbf{c}) n \mathrm{DIC},(\mathbf{d}) n \mathrm{TA}(\mu \mathrm{mol} \mathrm{kg}-1),(\mathbf{e}) \Omega_{\mathrm{arag}}$, and (f) $p \mathrm{CO}_{2}$ ( $\mu$ atm).

a shift from a deficit in $\Delta n$ TA to a surplus in $\Delta n$ TA at all stations, as well as a shift from a deficit in $\Delta n$ DIC to a surplus in $\Delta n \mathrm{DIC}$, suggesting a shift in the second sampling period from $\mathrm{CaCO}_{3}$ production to $\mathrm{CaCO}_{3}$ dissolution, and from photosynthesis to respiration. This change was most distinct at the two shallow sites. The $n \mathrm{TA}$ and $n \mathrm{DIC}$ values from the second sampling period were also enriched relative to a range of values reported from nearshore Oahu sites (Drupp et al., 2013) but consistent with coastal sites from Maunalua Bay, Oahu, with known inputs of SGD (Nelson et al., 2015; Richardson et al., 2017).

\section{Discussion}

The diurnal pattern observed at the four sampling sites along the reef flat is typical of a reef environment where biotic processes involving coral reef community metabolism (e.g., respiration/photosynthesis and calcification/dissolution) dominate the carbonate chemistry system (e.g., Smith, 1973). The non-linear relationship between salinity and carbonate chemistry parameters further supports the notion that biotic processes are driving carbonate chemistry variability along the reef flat (Millero et al., 1998; Ianson et al., 2003). The loweramplitude $n$ TA diurnal signal supports previous observations that the region was algal dominated (Smith et al., 2005). In 

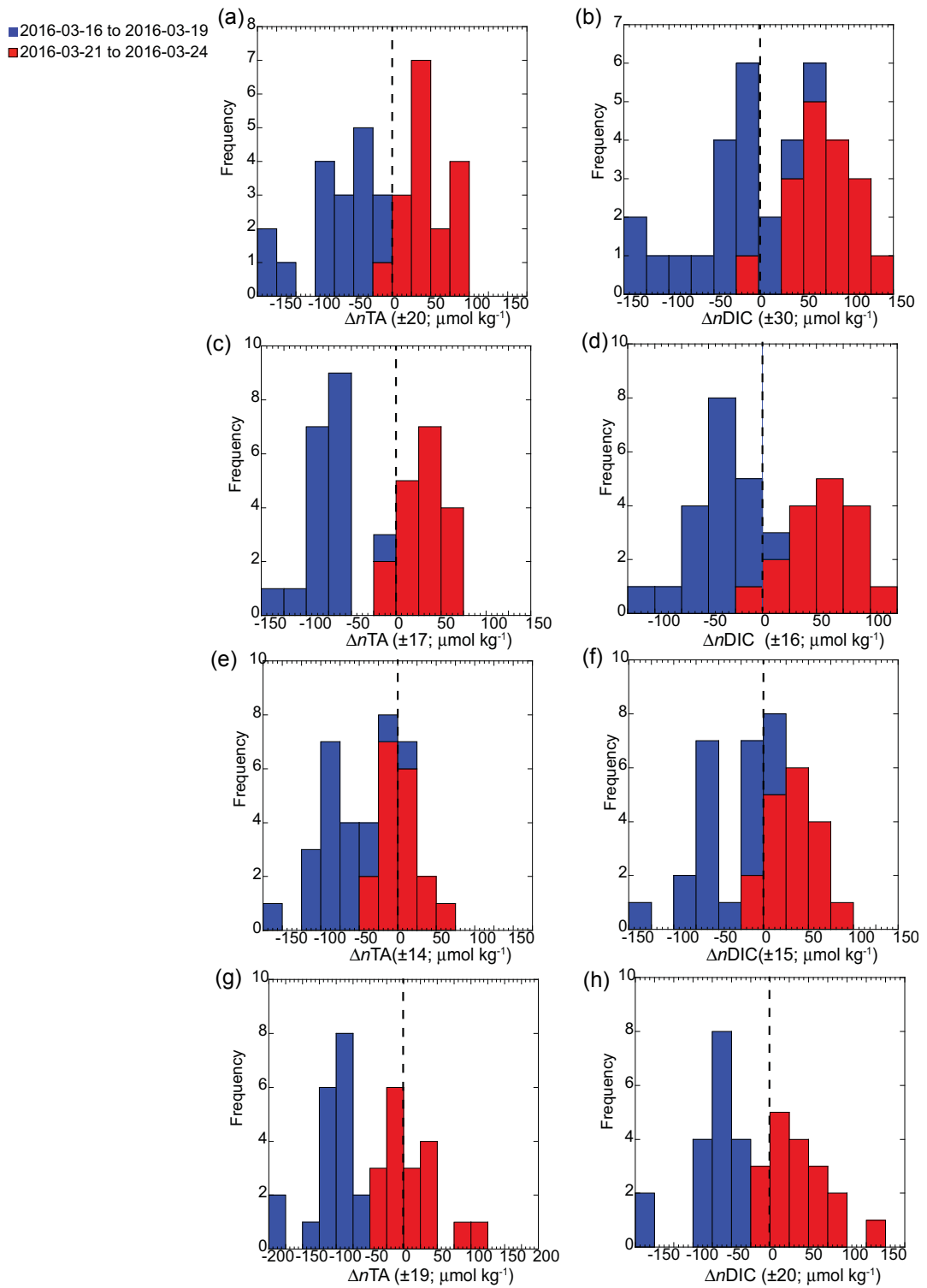

Figure 4. Histograms of $\Delta n \mathrm{TA}$ and $\Delta n \mathrm{DIC}$ capturing deficits and surpluses of $n \mathrm{TA}$ and $n \mathrm{DIC}$ with respect to open-ocean conditions. Overall, a transition from $\mathrm{CaCO}_{3}$ production to $\mathrm{CaCO}_{3}$ dissolution and photosynthesis to respiration occurred between the first (16 to $19 \mathrm{March} 2016$; blue) and second (21 to 24 March 2016; red) sampling periods for the shallow sampling sites (a-b) S1 and (c-d) S2, and the two deeper sites (e-f) S3 and (g-h) S4. Statistical $(p=0.05)$ deficit and surplus values $( \pm)$ for $\Delta n$ TA and $\Delta n$ TA are shown in parentheses.

this case, the lower biomass of calcifying organisms leads to conditions that favor respiration-photosynthesis processes relative to calcification-dissolution (Jokiel et al., 2014). Elevated $\mathrm{pH}$ values during midday, coincident with elevated sea surface temperature (SST) and peak solar irradiance, are consistent with maximum photosynthetic activity. DIC decreased during the day due to photosynthesis, whereas at nighttime, $\mathrm{pH}$ decreased and DIC increased in response to respiration (Fig. 3). This pattern is in stark contrast to the primary vent site where no diurnal pattern was observed, and abiotic controls on the carbonate system dynamics explain the strong linear relation to salinity. Variability at the vent site is driven by SGD rates, which are elevated during low tide when hydraulic gradients are the steepest (Dimova et al., 2012; Swarzenski et al., 2016). This spatial pattern is consistent with offshore transects from Maunalua Bay where sites closest to shore incorporated greater contribution of SGDderived TA and DIC than offshore sites (Richardson et al., 2017).

To further understand the temporal variability in carbonate chemistry over the 6-day sampling period along the reef flat, diagrams of $n$ TA versus $n$ DIC were plotted according to Zeebe and Wolf-Gladrow (2001), along with vectors indicating theoretical effects of net community production (NCP) 

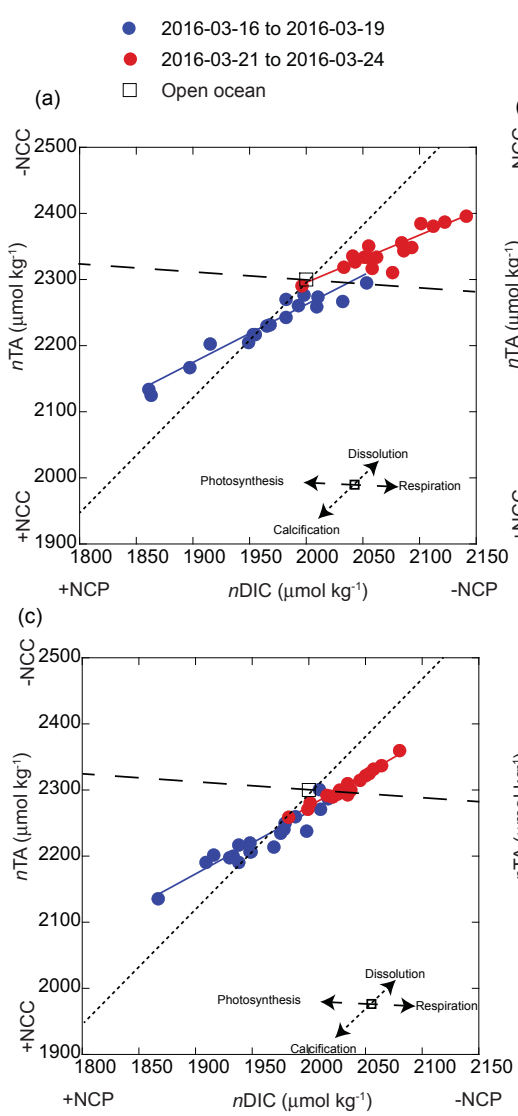

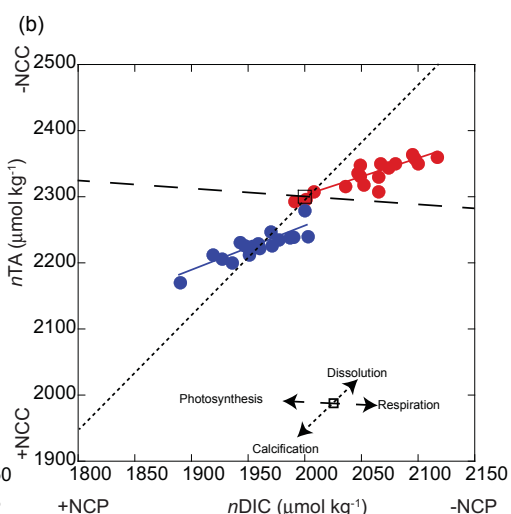

(d)

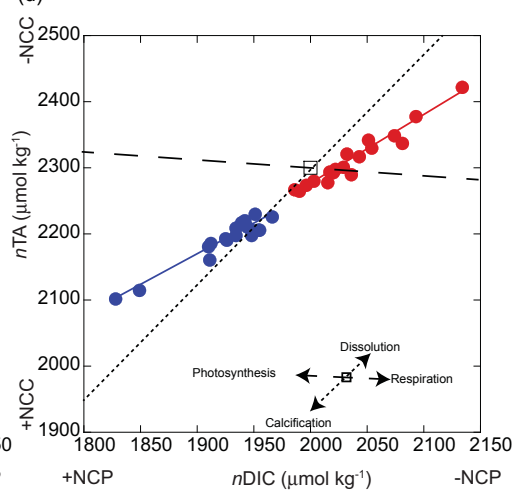

Figure 5. Seawater carbonate chemistry system along the reef flat off Kahekili as a function of $n$ DIC and $n$ TA for the shallow sampling sites (a) S1 and (b) S2, and two deeper sites (c) S3 and (d) S4, for the first (blue) and second (red) sampling periods and their respective slopes (solid lines) of $n$ DIC and $n$ TA (Table 1) and theoretical slope (dashed lines) given the predicted net effects of photosynthesis, respiration, calcification, and dissolution as shown in panels (a-d), and the respective change in net community calcification (NCC) and net community production (NCP). The relative positions of the open-ocean $n$ DIC and $n$ DIC values are reported as $1977 \pm 11$ and $2304 \pm 5 \mu \mathrm{mol} \mathrm{kg}^{-1}$ (adapted from Dore et al., 2009).

and net community calcification (NCC) on seawater chemistry (Kawahata et al., 1997; Suzuki and Kawahata, 2003) (Fig. 5). As presented here, NCP refers to the balance of photosynthesis and respiration, and NCC refers to the balance between calcification and dissolution (see review by Cyronak et al., 2018). Diagrams of $n \mathrm{TA}-n \mathrm{DIC}$ indicate the dominance of photosynthesis (+NCP) and $\mathrm{CaCO}_{3}$ precipitation (+NCC) during the first sampling period (16 March 2016 to 19 March 2016). The slope values of the $n$ DIC $-n$ TA plots were used to calculate ratios of NCC : NCP (Table 1) using methods of Suzuki and Kawahata (2003) to estimate the relative contribution of these processes to reef biogeochemistry. In the absence of reliable water mass residence time, ratios were used rather than metabolic rates. The NCC: NCP ratios for the first sampling period ranged from 0.50 to 0.88 , indicating a dominance of NCP relative to NCC. Plots of $n$ DIC- $n$ TA (Fig. 5) indicate that these sites were dominated primary by photosynthesis and calcification during $+\mathrm{NCP}$ and +NCC. This pattern was observed at all four sites along the reef flat. The lower NCC : NCP ratios at the shallow sites highlight the greater vulnerability of the shallow sites to dissolution under lower-pH conditions relative to the deeper. These results are in agreement with Richardson et al. (2017) who found dissolution at reef sites closest to groundwater vents in Maunalua Bay, Oahu. A shift occurred at all sampling sites after the first sampling period. Elevated $n$ DIC and $n$ TA values from 21 to 22 March 2016 indicate a shift to respiration and dissolution in the $n \mathrm{TA}-n \mathrm{DIC}$ diagrams during -NCC and -NCP (Fig. 5). At the shallow sites, S1 and S2 (Fig. 5a and b), the NCC : NCP ratios were 0.56 and 0.39 during the second sampling period (Table 1), respectively, indicating the dominance of NCP relative to NCC. In comparison, at sites S3 and S4 located further offshore, dissolution and respiration contributed nearly equally, with NCC : NCP ratios near 1.0 during the second sampling. Given the salinity range along the reef flat (34 to 36), traditional salinity normalization (e.g., Friis et al., 2003) could potentially overestimate the $n$ DIC and $n$ TA concentrations by $\sim 20$ to $\sim 10 \mu \mathrm{mol} \mathrm{kg}^{-1}$, respectively, according to non-zero normalization described in Richardson et al. (2017). However, rather 
Table 1. Slope of salinity normalized total alkalinity ( $n$ TA) to salinity normalized dissolved inorganic carbon (DIC), net community calcification to net community production ratio $(\mathrm{NCC}: \mathrm{NCP}=2 \Delta \mathrm{DIC} /(\Delta \mathrm{TA}-1))$ (Suzuki and Kawahata, 2003), and correlation coefficients $\left(r^{2}\right)$.

\begin{tabular}{lrrr}
\hline Site & $\begin{array}{r}n \text { TA- } n \text { DIC } \\
\text { slope }\end{array}$ & NCC: NCP & $r^{2}$ \\
\hline \multicolumn{1}{l}{ 16-19 } & March 2016 & & \\
\hline S1 & 0.88 & 0.78 & 0.94 \\
S2 & 0.67 & 0.50 & 0.75 \\
S3 & 0.93 & 0.88 & 0.89 \\
S4 & 0.93 & 0.87 & 0.92 \\
\hline 21-24 March 2016 & & \\
\hline S1 & 0.72 & 0.56 & 0.78 \\
S2 & 0.56 & 0.39 & 0.77 \\
S3 & 0.99 & 0.98 & 0.95 \\
S4 & 1.04 & 1.08 & 0.94 \\
\hline
\end{tabular}

than reflecting an artifact of the salinity normalization, given the non-linear relation of DIC and TA to salinity along the reef flat (Supplement, Fig. S1), this shift is interpreted as a reef community response. As shown in Figs. 4 and 5, this change captures a shift from a reef community dominated by calcification and photosynthesis to one dominated by respiration and dissolution during $-\mathrm{NCC}$ and $-\mathrm{NCP}$.

The shift from photosynthesis $(P)$ to respiration $(R)$, as captured in the $\Delta n$ DIC histogram plots (Fig. 4), suggests that the coral-algal association consumed more energy than it produced during the second sampling period. As a proxy for autotrophic capacity, the change in $P: R$ ratio may reflect an increase in coral heterotrophic feeding relative to autotrophic feeding (Coles and Jokiel, 1977; Hughes and Grottoli, 2013). Typically, stored lipid reserves in the tissue are utilized when the stable symbiotic environment is disturbed (e.g., Szmant and Gassman, 1990; Ainsworth et al., 2008). Although shortlived, thermally induced bleaching has been linked to depletion of coral lipid reserves (e.g., Hughes and Grottoli, 2013), and excess nutrient loading can also shift the stability of the coral-algae symbiosis, thereby reducing stored tissue reserves (Wooldridge, 2016). According to Glenn et al. (2013), up to $11 \mathrm{~m}^{3} \mathrm{~d}^{-1}$ of dissolved inorganic nitrogen are discharged onto the West Maui reef as the result of receiving and treating over $15000 \mathrm{~m}^{3} \mathrm{~d}^{-1}$ of sewage. Using a SGD flux rate of $87 \mathrm{~cm} \mathrm{~d}^{-1}$ at the primary seep site (Swarzenski et al., 2016), and SGD nitrate endmember concentration of $117 \mu \mathrm{mol} \mathrm{L}^{-1}$ (Prouty et al., 2017b), the nitrate flux from the primary vent site is $712 \mathrm{~mol} \mathrm{~d}^{-1}$, clearly demonstrating excess nutrient loading. Elevated SGD endmember nutrient concentrations are consistent with those observed from Black Point, Maunalua Bay, where effluent from proximal on-site sewage disposal is linked to excess nitrogen loads (Nelson et al., 2015; Richardson et al., 2017). As described above, an offshore gradient in nutrient concentrations was observed with enriched nutrients at the shallow sites compared to the deeper sites, consistent with a decrease in coral $\delta^{15} \mathrm{~N}$ values away from the vent (Prouty et al., 2017a). Coral tissue thickness was also negatively correlated to coral tissue $\delta^{15} \mathrm{~N}$ values $(r=-0.66 ; p=0.08)$, with the latter serving as a proxy for nutrient loading in algae samples along the reef flat (Dailer et al., 2010). It is possible that a reduction in coral tissue reflects preferential heterotrophic feeding under high nutrient loading, with nutrient enrichment by sewage effluent increasing primary production and biomass in the water column (e.g., Smith et al., 1981; Pastorok and Bilyard, 1985). While assessing the impacts of nutrient loading on coral physiology may be long term and subtle in some cases, results from our study highlight the potential short-term impacts of nutrification.

Identifying the exact mechanism(s) responsible for driving this shift is difficult given the complexity of the reef system. Possible explanations include warmer SSTs and suspension of organic matter, as well as secondary effects of nutrification from contaminated SGD (D'Angelo and Wiedenmann, 2014). Given that microbial communities rapidly take up inorganic nutrients (Furnas et al., 2005), there could be increased respiration as a result of increased microbial remineralization of organic matter in the nutrient-loaded environment (Sunda and Cai, 2012). In other words, enhanced SGD-driven nutrient fluxes during the second sampling period could have increased microbial growth and remineralization, shifting the reef community metabolism, as captured in a shift in the carbonate chemistry system. In addition to community metabolism, local oceanographic effects such as the wind and wave regime can also drive carbonate chemistry by altering air-sea exchange and water mass residence times. During the first sampling period, the wave height increased from 0.4 to $1.6 \mathrm{~m}$ over the first 2 days and mean current speeds were $1.6 \mathrm{~cm} \mathrm{~s}^{-1}$ as wind speeds increased (Supplement, Fig. S2). In comparison, during the second sampling period, wave height declined to less than $0.4 \mathrm{~m}$ and mean current speeds were $1.0 \mathrm{~cm} \mathrm{~s}^{-1}$. Together, the reduced wave height and reduced wind speeds favor slower release of $\mathrm{CO}_{2}$ generated by calcification and respiration processes from the water column (Massaro et al., 2012), resulting in higher $p \mathrm{CO}_{2}$ and lower $\mathrm{pH}$.

Despite being situated in an oligotrophic region with naturally occurring, low nutrient concentrations, anthropogenic nutrient loading to coastal waters via sustained SGD is driving nearshore eutrophication (Dailer et al., 2010, 2012; Bishop et al., 2015; Amato et al., 2016; Fackrell et al., 2016), with algal $\delta^{15} \mathrm{~N}$ signatures at Kahekili Beach Park indicative of wastewater effluent (Dailer et al., 2010, 2012). In response, there has been a shift in benthic cover from abundant corals to turf or macro-algae over the last two decades. Areas of discrete coral cover loss up to $100 \%$ along the shallow coral reef at Kahekili have been observed for decades 
(Wiltse, 1996; Ross et al., 2012), with a history of macroalgal blooms (Smith et al., 2005). More recently, Prouty et al. (2017a) found accelerated nutrient-driven bioerosion from coral cores collected along the Kahekili reef flat in response to land-based sources of nutrients. This is consistent with earlier work showing nutrification-mediated increase in plankton loads can trigger increases in filter feeders and bioeroders that endanger reef structure integrity (e.g., Fabricius et al., 2012). Eutrophication from nutrient-enriched SGD may contribute to an already compromised carbonate system (i.e., reduced $\mathrm{pH}$ and $\Omega_{\mathrm{arag}}$ ) by increasing respiration and remineralization of excess organic matter, and increasing bioerosion. Therefore, secondary effects of nutrient-driven increase in phytoplankton biomass and decomposing organic matter are also important considerations for coral reef management (D'Angelo and Wiedenmann, 2014).

As discussed above, SGD rates are elevated during low tide when the relative pressure head difference between terrestrial groundwater and the oceanic water column is greatest (Dimova et al., 2012; Swarzenski et al., 2016). Relative SGD is greater in the shallows close to shore where the tidal height is larger relative to the depth of the water column. Higher islands, therefore, have the potential for not only greater orographic rainfall, and thus submarine groundwater recharge, but also greater potential pressure head and thus enhanced SGD-driven nutrient fluxes. There is also greater potential for enriched nutrient sources and reduced water quality with fast-growing population and development (Amato et al., 2016; Fackrell et al., 2016). Thus, SGD represents a key vector of nutrient loading in tropical, oligotrophic regions (e.g., Paytan et al., 2006). At the same time, closer to shore, current speeds are generally slower resulting in longer water mass residence times (Storlazzi et al., 2006); longer residence times would also be expected closer to the seabed, compared with upper water column flows (Storlazzi and Jaffe, 2008). Together, these suggest that the resulting exposure (the product of intensity multiplied by residence time) of coral reefs to nutrient-laden, low-pH submarine groundwater is greater for coral reefs closer to shore off high islands than along barrier reefs or on atolls. This heightened vulnerability therefore needs to be taken into account when evaluating vulnerability of nearshore fringing reefs to changes in carbonate chemistry system given evidence of nutrientdriven bioerosion from land-based sources of pollution.

\section{Conclusion}

Field based measurements of carbonate chemistry variability were made along a shallow coral reef off Kahekili, West Maui, and captured differences in the relative importance of inorganic and organic carbon production over a 6-day period in March 2016. Submarine groundwater discharge fluxes controlled the carbonate chemistry adjacent to the primary vent site, with nutrient-laden freshwater decreasing the $\mathrm{pH}$ levels and favoring undersaturated $\Omega_{\mathrm{arag}}$ conditions. In contrast, reef community metabolism dominated the carbonate chemistry diurnal signal at sites along the reef flat. Superimposed on the diurnal signal was a transition during the second sampling period, yielding a surplus of $n \mathrm{TA}$ and $n \mathrm{DIC}$ compared to ocean endmember measurements indicating a shift from photosynthesis and calcification during + NCP and $+\mathrm{NCC}$ to respiration and carbonate dissolution during $-\mathrm{NCC}$ and $-\mathrm{NCP}$. This shift could be interpreted as a direct response to increased nutrient loading and subsequent enhancement of organic matter remineralization. Predictions of reef response to elevated $p \mathrm{CO}_{2}$ levels assume reef water tracks open-ocean $\mathrm{pH}$; however, local effects are equally important (e.g., Cyronak et al., 2013, 2018), particularly along densely inhabited shorelines with known input from landbased sources of pollution. Building on previous work documenting the input of nutrient-laden, low-pH freshwater to the reefs off Kahekili, results presented here offer a first glimpse into how anthropogenic-driven eutrophication might add an additional stressor to thresholds tipping the balance between net carbonate accretion and net carbonate dissolution, thus altering carbonate system dynamics.

Data availability. Data used in this article are available at https://doi.org/10.5066/F7X34VPV (Prouty et al., 2017b).

Supplement. The supplement related to this article is available online at: https://doi.org/10.5194/bg-15-2467-2018-supplement.

Author contributions. NGP and KKY designed the experiments and NGP, KKY, NS, and CG carried them out. NGP and KKY completed the chemical measurements and OC compiled the oceanographic data. NGP prepared the manuscript with contributions from all co-authors.

Competing interests. The authors declare that they have no conflict of interest.

Acknowledgements. This research was carried out as part of the US Geological Survey Coral Reefs Project in an effort to better understand the effects of geologic and oceanographic processes on coral reef systems in the USA and its trust territories, and was supported by the USGS Coastal and Marine Geology Program. The authors gratefully acknowledge the vital partnership and expert logistics support provided by the State of Hawaii Division of Aquatic Resources. We thank Thomas DeCarlo (UWA), Hannah Barkley (NOAA), two anonymous reviewers, and Jean-Pierre Gattuso for their valuable reviews, Anne Cohen (WHOI) for helpful discussions, and Kathryn Pietro and Katherine Hoering (WHOI), Christopher Moore (USGS), and Georges Paradis (UCSB) analytical assistance, and Meghan Dailer (U. Hawaii) for field assistance. The use of trade names is for descriptive purposes only and does 
not imply endorsement by the US Government. Additional data to support this project can be found in Prouty et al. (2017b).

Edited by: Jean-Pierre Gattuso

Reviewed by: two anonymous referees

\section{References}

Ainsworth, T. D., Hoegh-Guldberg, O., Heron, S. F., Skirving, W. J., and Leggat, W.: Early cellular changes are indicators of prebleaching thermal stress in the coral host, J. Exp. Mar. Biol. Ecol., 364, 63-71, https://doi.org/10.1016/j.jembe.2008.06.032, 2008.

Albright, R., Benthuysen, J., Cantin, N., Caldeira, K., and Anthony, K.: Coral reef metabolism and carbon chemistry dynamics of a coral reef flat, Geophys. Res. Lett., 42, 3980-3988, https://doi.org/10.1002/2015GL063488, 2015.

Amato, D. W., Bishop, J. M., Glenn, C. R., Dulai, H., and Smith, C. M.: Impact of submarine groundwater discharge on marine water quality and reef biota of Maui, PLOS ONE, 11, e0165825, https://doi.org/10.1371/journal.pone.0165825 2016.

Anderson, D. M., Glibert, P. M., and Burkholder, J. M.: Harmful algal blooms and eutrophication: nutrient sources, composition and consequences, Estuaries, 25, 562-584, https://doi.org/10.1007/BF02804901, 2002.

Andersson, A. J. and Gledhill, D.: Ocean acidification and coral reefs: effects on breakdown, dissolution, and net ecosystem calcification, Annu. Rev. Mar. Sci., 5, 321-348, 2013.

Andrefouet, S., Mumby, P. J., McField, M., Hu, C., and MullerKarger, F. E.: Revisiting coral reef connectivity, Coral Reefs, 21, 43-48, https://doi.org/10.1007/s00338-001-0199-0, 2002.

Bernstein, W. N., Hughen, K. A., Langdon, C., McCorkle, D. C., and Lentz, S. J.: Environmental controls on daytime net community calcification on a Red Sea reef flat, Coral Reefs, 35, 697711, 2016

Bishop, J. M., Glenn, C. R., Amato, D. W., and Dulai, H.: Effect of land use and groundwater flow path on submarine groundwater discharge nutrient flux, J. Hydrol.: Regional Studies, 11, 194218, https://doi.org/10.1016/j.ejrh.2015.10.008, 2015.

Cai, W.-J., Hu, X., Huang, W.-J., Murrell, M. C., Lehrter, J. C., Lohrenz, S. E., Chou, W.-C., Zhai, W., Hollibaugh, J. T., Wang, Y., Zhao, P., Guo, X., Gundersen, K., Dai, M., and Gong, G.-C.: Acidification of subsurface coastal waters enhanced by eutrophication, Nat. Geosci., 4, 766-770, https://doi.org/10.1038/ngeo1297, 2011.

Cochran, S. A., Gibbs, A. E., and White, D. J.: Benthic habitat map of the U.S. Coral Reef Task Force Watershed Partnership Initiative Kāanapali priority study area and the State of Hawai'i Kahekili Herbivore Fisheries Management Area, west-central Maui, Hawai'i, U.S. Geological Survey Open-File Report 2014-1129, 2014.

Coles, S. L. and Jokiel, P. L.: Effects of temperature on photosynthesis and respiration in hermatypic corals, Mar. Biol., 43, 209-216, https://doi.org/10.1007/BF00402313, 1977.

Cyronak, T., Santos, I. R., and Eyre, B. D.: Permeable coral reef sediment dissolution driven by elevated $\mathrm{pCO}_{2}$ and pore water advection, Geophys. Res. Lett., 40, 4876-4881, https://doi.org/10.1002/grl.50948, 2013.
Cyronak, T., Andersson, A. J., Langdon, C., Albright, R., Bates, N. R., Caldeira, K., Carlton, R., Corredor, J. E., Dunbar, R. B., Enochs, I., Erez, J., Eyre, B. D., Gattuso, J.-P., Gledhill, D., Kayanne, H., Kline, D. I., Koweek, D. A., Lantz, C., Lazar, B., Manzello, D., McMahon, A., Meléndez, M., Page, H. N., Santos, I. R., Schulz, K. G., Shaw, E., Silverman, J., Suzuki, A., Teneva, L., Watanabe, A., and Yamamoto, S.: Taking the metabolic pulse of the world's coral reefs, PLOS ONE, 13, e0190872, https://doi.org/10.1371/journal.pone.0190872, 2018.

Dailer, M. L., Knox, R. S., Smith, J. E., Napier, M., and Smith, C. M.: Using $\delta^{15} \mathrm{~N}$ values in algal tissue to map locations and potential sources of anthropogenic nutrient inputs on the island of Maui, Hawai'i, USA, Mar. Pollut. Bull., 60, 655-671, https://doi.org/10.1016/j.marpolbul.2009.12.021, 2010.

Dailer, M. L., Ramey, H. L., Saephan, S., and Smith, C. M.: Algal $\delta^{15} \mathrm{~N}$ values detect a wastewater effluent plume in nearshore and offshore surface waters and three-dimensionally model the plume across a coral reef on Maui, Hawai'i, USA, Mar. Pollut. Bull., 64, 207-213, https://doi.org/10.1016/j.marpolbul.2011.12.004, 2012.

D'Angelo, C. and Wiedenmann, J.: Impacts of nutrient enrichment on coral reefs: new perspectives and implications for coastal management and reef survival, Curr. Opin. Env. Sust., 7, 82-93, https://doi.org/10.1016/j.cosust.2013.11.029, 2014.

DeCarlo, T. M., Cohen, A. L., Wong, G. T. F., Shiah, F. K., Lentz, S. J., Davis, K. A., Shamberger, K. E. F., and Lohmann, P.: Community production modulates coral reef $\mathrm{pH}$ and the sensitivity of ecosystem calcification to ocean acidification, J. Geophys. Res.Oceans, 122, 745-761, https://doi.org/10.1002/2016JC012326, 2017.

Dickson, A. G.: An exact definition of total alkalinity and a procedure for the estimation of alkalinity and total inorganic carbon from titration data, Deep-Sea Res. Pt. A, 28, 609-623, 1981.

Dickson, A. G.: Thermodynamics of the dissociation of boric acid in synthetic seawater from 273.15 to $318.15 \mathrm{~K}$, Deep-Sea Res. Pt. A, 37, 755-766, https://doi.org/10.1016/0198-0149(90)90004-F, 1990.

Dickson, A. G. and Millero, F. J.: A comparison of the equilibrium constants for the dissociation of carbonic acid in seawater media, Deep-Sea Res. Pt. A, 34, 1733-1743, https://doi.org/10.1016/0198-0149(87)90021-5, 1987.

Dickson, A. G., Sabine, C. L., and Christian, J. R.: Guide to best practices for ocean $\mathrm{CO}_{2}$ measurements, PICES Special Publication, 3, 176, 191 pp., 2007.

Dimova, N. T., Swarzenski, P. W., Dulaiova, H., and Glenn, C. R.: Utilizing multichannel electrical resistivity methods to examine the dynamics of the fresh water-seawater interface in two Hawaiian groundwater systems, J. Geophys. Res.-Oceans, 117, C02012, https://doi.org/10.1029/2011jc007509, 2012.

Dore, J. E., Lukas, R., Sadler, D. W., Church, M. J., and Karl, D. M.: Physical and biogeochemical modulation of ocean acidification in the central North Pacific, P. Natl. Acad. Sci. USA, 106, 1223512240, 2009.

Drupp, P. S., De Carlo, E. H., Mackenzie, F. T., Sabine, C. L., Feely, R. A., and Shamberger, K. E.: Comparison of $\mathrm{CO}_{2}$ dynamics and air-sea gas exchange in differing tropical reef environments, Aquat. Geochem., 19, 371-397, 2013. 
Fabricius, K. E.: Effects of terrestrial runoff on the ecology of corals and coral reefs: review and synthesis, Mar. Pollut. Bull., 50, 125146, https://doi.org/10.1016/j.marpolbul.2004.11.028, 2005.

Fabricius, K. E., Cooper, T. F., Humphrey, C., Uthicke, S., De'ath, G., Davidson, J., LeGrand, H., Thompson, A., and Schaffelke, B.: A bioindicator system for water quality on inshore coral reefs of the Great Barrier Reef, Mar. Pollut. Bull., 65, 320-332, https://doi.org/10.1016/j.marpolbul.2011.09.004, 2012.

Fackrell, J. K., Glenn, C. R., Popp, B. N., Whittier, R. B., and Dulai, H.: Wastewater injection, aquifer biogeochemical reactions, and resultant groundwater $\mathrm{N}$ fluxes to coastal waters: Kā'anapali, Maui, Hawai'i, Mar. Pollut. Bull., 110, 281-292, https://doi.org/10.1016/j.marpolbul.2016.06.050, 2016.

Ferrario, F., Beck, M. W., Storlazzi, C. D., Micheli, F., Shepard, C. C., and Airoldi, L.: The effectiveness of coral reefs for coastal hazard risk reduction and adaptation, Nat. Commun., 5, 3794, https://doi.org/10.1038/ncomms4794, 2014.

Friis, K., Körtzinger, A., and Wallace, D. W. R.: The salinity normalization of marine inorganic carbon chemistry data, Geophys. Res. Lett., 30, 1085, https://doi.org/10.1029/2002GL015898, 2003.

Furnas, M., Mitchell, A., Skuza, M., and Brodie, J.: In the other $90 \%$ : phytoplankton responses to enhanced nutrient availability in the Great Barrier Reef Lagoon, Mar. Pollut. Bull., 51, 253265, https://doi.org/10.1016/j.marpolbul.2004.11.010, 2005.

Giambelluca, T. W., Chen, Q., Frazier, A. G., Price, J. P., Chen, Y.-L., Chu, P.-S., Eischeid, J. K., and Delparte, D. M.: Online Rainfall Atlas of Hawai'i, B. Am. Meteorol. Soc., 94, 313-316, https://doi.org/10.1175/BAMS-D-11-00228.1, 2013.

Gingerich, S. B. and Engott, J. A.: Groundwater availability in the Lahaina District, West Maui, Hawai'i, 90 pp., 2012.

Glenn, C. R., Whittier, R. B., Dailer, M. L., Dulaiova, H., El-Kadi, A. I., Fackrell, J., Kelly, J. L., Waters, C. A., and Sevadjian, L.: Lahaina Groundwater Tracer Study - Lahaina, Maui, Hawaii, Final Report, State of Hawaii Department of Health, the U.S. Environmental Protection Agency, and the U.S. Army Engineer Research and Development Center, 2013.

Howarth, R., Anderson, D., Cloern, J., Elfring, C., Hopkinson, C., Lapointe, B., Malone, T., Marcus, N., McGlathery, K., Sharpley, A., and Walker, D.: Nutrient pollution of coastal rivers, bays, and seas, Issues in Ecology, 7, 1-15, 2000.

Hughes, A. D. and Grottoli, A. G.: Heterotrophic compensation: A possible mechanism for resilience of coral reefs to global warming or a sign of prolonged stress?, PLOS ONE, 8, e81172, https://doi.org/10.1371/journal.pone.0081172, 2013.

Hughes, T. P., Baird, A. H., Bellwood, D. R., Card, M., Connolly, S. R., Folke, C., Grosberg, R., Hoegh-Guldberg, O., Jackson, J. B. C., Kleypas, J., Lough, J. M., Marshall, P., Nystrom, M., Palumbi, S. R., Pandolfi, J. M., Rosen, B., and Roughgarden, J.: Climate change, human impacts, and the resilience of coral reefs, Science, 301, 929-933, https://doi.org/10.1126/science.1085046, 2003.

Hughes, T. P., Rodrigues, M. J., Bellwood, D. R., Ceccarelli, D., Hoegh-Guldberg, O., McCook, L., Moltschaniwskyj, N., Pratchett, M. S., Steneck, R. S., and Willis, B.: Phase shifts, serbivory, and the resilience of coral reefs to climate change, Curr. Biol., 17, 360-365, https://doi.org/10.1016/j.cub.2006.12.049, 2007.

Ianson, D., Allen, S. E., Harris, S. L., Orians, K. J., Varela, D. E., and Wong, C. S.: The inorganic carbon system in the coastal upwelling region west of Vancouver Island, Canada, DeepSea Res. Pt. I, 50, 1023-1042, https://doi.org/10.1016/S09670637(03)00114-6, 2003.

Jokiel, P. L., Jury, C. P., and Ku'ulei, S. R.: Coral-algae metabolism and diurnal changes in the $\mathrm{CO}_{2}$-carbonate system of bulk sea water, PeerJ, 2, e378, https://doi.org/10.7717/peerj.378, 2014.

Kawahata, H., Suzuki, A., and Goto, K.: Coral reef ecosystems as a source of atmospheric $\mathrm{CO}_{2}$ : evidence from $\mathrm{pCO}_{2}$ measurements of surface waters, Coral Reefs, 16, 261-266, https://doi.org/10.1007/s003380050082, 1997.

Knowlton, N. and Jackson, J. B. C.: Shifting baselines, local impacts, and global change on coral reefs, PLoS Biol, 6, e54, https://doi.org/10.1371/journal.pbio.0060054, 2008.

Langenheim, V. A. M. and Clague, D. A.: The Hawaiiian-Emperor volcanic chain. Part II. Stratigraphic framework of volcanic rocks of the Hawaiian Islands, U.S. Geological Survey Professional Paper 1350, 55-84, 1987.

Lantz, C. A., Atkinson, M. J., Winn, C. W., and Kahng, S. E.: Dissolved inorganic carbon and total alkalinity of a Hawaiian fringing reef: chemical techniques for monitoring the effects of ocean acidification on coral reefs, Coral Reefs, 33, 105-115, 2014.

Lapointe, B. E., Barile, P. J., Littler, M. M., and Littler, D. S.: Macroalgal blooms on southeast Florida coral reefs. II. Cross-shelf $\delta^{15} \mathrm{~N}$ values provide evidence of widespread sewage enrichment, Harmful Algae, 4, 1106-1122, https://doi.org/10.1016/j.hal.2005.06.004, 2005.

Massaro, R. F. S., De Carlo, E. H., Drupp, P. S., Mackenzie, F. T., Jones, S. M., Shamberger, K. E., Sabine, C. L., and Feely, R. A.: Multiple factors driving variability of $\mathrm{CO}_{2}$ exchange between the ocean and atmosphere in a tropical coral reef environment, Aquat. Geochem., 18, 357-386, 2012.

McIlvin, M. R. and Altabet, M. A.: Chemical conversion of nitrate and nitrite to nitrous oxide for nitrogen and oxygen isotopic analysis in freshwater and seawater, Anal. Chem., 77, 5589-5595, https://doi.org/10.1021/ac050528s, 2005.

Mehrbach, C., Culberson, C. H., Hawley, J. E., and Pytkowicx, R. M.: Measurement of the apparent dissociation constants of carbonic acid in seawater at atmospheric pressure, Limnol. Oceanogr., 18, 897-907, https://doi.org/10.4319/lo.1973.18.6.0897, 1973.

Millero, F. J., Lee, K., and Roche, M.: Distribution of alkalinity in the surface waters of the major oceans, Mar. Chem., 60, 111-130, https://doi.org/10.1016/S0304-4203(97)00084-4, 1998.

Muehllehner, N., Langdon, C., Venti, A., and Kadko, D.: Dynamics of carbonate chemistry, production, and calcification of the Florida Reef Tract (2009-2010): Evidence for seasonal dissolution, Global Biogeochem. Cy., 30, 661-688, https://doi.org/10.1002/2015GB005327, 2016.

Nelson, C. E., Donahue, M. J., Dulaiova, H., Goldberg, S. J., La Valle, F. F., Lubarsky, K., Miyano, J., Richardson, C., Silbiger, N. J., and Thomas, F. I. M.: Fluorescent dissolved organic matter as a multivariate biogeochemical tracer of submarine groundwater discharge in coral reef ecosystems, Mar. Chem., 177, 232-243, https://doi.org/10.1016/j.marchem.2015.06.026, 2015.

Orr, J. C., Fabry, V. J., Aumont, O., Bopp, L., Doney, S. C., Feely, R. A., Gnanadesikan, A., Gruber, N., Ishida, A., Joos, F., Key, R. M., Lindsay, K., Maier-Reimer, E., Matear, R., Monfray, P., Mouchet, A., Najjar, R. G., Plattner, G.-K., Rodgers, K. B., Sabine, C. L., Sarmiento, J. L., Schlitzer, R., Slater, R. D., Totterdell, I. J., 
Weirig, M.-F., Yamanaka, Y., and Yool, A.: Anthropogenic ocean acidification over the twenty-first century and its impact on calcifying organisms, Nature, 437, 681-686, 2005.

Page, H. N., Courtney, T. A., Collins, A., De Carlo, E. H., and Andersson, A. J.: Net community metabolism and seawater carbonate chemistry scale non-intuitively with coral cover, Front. Mar. Sci., 4, 161, https://doi.org/10.3389/fmars.2017.00161, 2017.

Pastorok, R. A. and Bilyard, G. R.: Effects of sewage pollution on coral-reef communities, Mar. Ecol.-Prog. Ser., 175-189, 1985.

Paytan, A., Shellenbarger, G. G., Street, J. H., Gonneea, M. E., Davis, K., Young, M. B., and Moore, W. S.: Submarine groundwater discharge: An important source of new inorganic nitrogen to coral reef ecosystems, Limnol. Oceanogr., 51, 343-348, https://doi.org/10.4319/1o.2006.51.1.0343, 2006.

Pierrot, D., Lewis, E., and Wallace, D. W. R.: MS Excel program developed for $\mathrm{CO}_{2}$ system calculations, https://doi.org/ 10.3334/CDIAC/otg.CO2SYS_XLS_CDIAC105a, 2006.

Press, W. H., Flannery, B. P., Teukolsky, S. A., and Vetterling, W. T.: Numerical Recipes in C, Cambridge University Press, New York, 1988.

Prouty, N. G., Cohen, A., Yates, K. K., Storlazzi, C. D., Swarzenski, P. W., and White, D.: Vulnerability of coral reefs to bioerosion from land-based sources of pollution, J. Geophys. Res.-Oceans, 122, 9319-9331, https://doi.org/10.1002/2017JC013264, 2017a.

Prouty, N. G., Yates, K. K., Smiley, N. A., and Gallagher, C.: Coral growth parameters and seawater chemistry, Kahekili, west Maui: U.S. Geological Survey data release, https://doi.org/10.5066/F7X34VPV, 2017b.

Richardson, C. M., Dulai, H., Popp, B. N., Ruttenberg, K., and Fackrell, J. K.: Submarine groundwater discharge drives biogeochemistry in two Hawaiian reefs, Limnol. Oceanogr., 62, S348S363, https://doi.org/10.1002/lno.10654, 2017.

Rodgers, K. U. S., Jokiel, P. L., Brown, E. K., Hau, S., and Sparks, R.: Over a decade of change in spatial and temporal dynamics of Hawaiian coral reef communities 1, Pac. Sci., 69, 1-13, https://doi.org/10.2984/69.1.1, 2015.

Ross, M., White, D., Aiwohi, M., Walton, M., Sudek, M., Lager, D., and Jokiel, P.: Characterization of "dead zones" and population demography of Porites compressa along a gradient of anthropogenic nutrient input at Kahekili Beach Park, Maui, State of Hawaii, Department of Land and Natural Resources, Division of Aquatic Resources, Honolulu, Hawaii 96813, 2012.

Ryabenko, E., Altabet, M. A., and Wallace, D. W. R.: Effect of chloride on the chemical conversion of nitrate to nitrous oxide for $\delta^{15} \mathrm{~N}$ analysis, Limnol. Oceanogr.-Meth., 7, 545-552, https://doi.org/10.4319/lom.2009.7.545, 2009.

Shamberger, K. E. F., Feely, R. A., Sabine, C. L., Atkinson, M. J., DeCarlo, E. H., Mackenzie, F. T., Drupp, P. S., and Butterfield, D. A.: Calcification and organic production on a Hawaiian coral reef, Mar. Chem., 127, 64-75, 2011.

Shaw, E. C., McNeil, B. I., and Tilbrook, B.: Impacts of ocean acidification in naturally variable coral reef flat ecosystems, J. Geophys. Res.-Oceans, 117, C03038, https://doi.org/10.1029/2011JC007655, 2012.

Sigman, D. M., Casciotti, K. L., Andreani, M., Barford, C., Galanter, M., and Bohlke, J. K.: A bacterial method for the nitrogen isotopic analysis of nitrate in seawater and freshwater, Anal. Chem., 73, 4145-4415, https://doi.org/10.1021/ac010088e, 2001
Silbiger, N. J., Donahue, M. J., and Brainard, R. E.: Environmental drivers of coral reef carbonate production and bioerosion: a multi-scale analysis, Ecology, 98, 2547-2560, https://doi.org/10.1002/ecy.1946, 2017.

Silverman, J., Lazar, B., and Erez, J.: Community metabolism of a coral reef exposed to naturally varying dissolved inorganic nutrient loads, Biogeochemistry, 84, 67-82, 2007.

Silverman, J., Lazar, B., Cao, L., Caldeira, K., and Erez, J.: Coral reefs may start dissolving when atmospheric $\mathrm{CO}_{2}$ doubles, Geophys. Res. Lett., 36, L05606, https://doi.org/10.1029/2008GL036282, 2009.

Smith, J. E., Runcie, J. W., and Smith, C. M.: Characterization of a large-scale ephemeral bloom of the green alga Cladophora sericea on the coral reefs of West Maui, Hawaii, Mar. Ecol.-Prog. Ser., 302, 77-91, 2005.

Smith, S. V.: Carbon dioxide dynamics: a record of organic carbon production, respiration, and calcification in the Eniwetok reef flat community, Limnol. Oceanogr., 18, 106-120, 1973.

Smith, S. V., Kimmerer, W. J., Laws, E. A., Brock, R. E., and Walsh, T. W.: Kaneohe Bay sewage diversion experiment: perspectives on ecosystem responses to nutritional perturbation, Pac. Sci., 35 , 279-395, 1981.

Sparks, R. T., Stone, K., White, D. J., Ross, M., and Williams, I. D.: Maui and Lanai Monitoring Report, Hawaii Department of Land and Natural Resources, Division of Aquatic Resources, Maui, 130 Mahalani Street, Wailuku HI, 96790, 2016.

Storlazzi, C. D. and Jaffe, B. E.: The relative contribution of processes driving variability in flow, shear, and turbidity over a fringing coral reef: West Maui, Hawaii, Estuar. Coast. Shelf Sc., 77, 549-564, https://doi.org/10.1016/j.ecss.2007.10.012, 2008.

Storlazzi, C. D., McManus, M. A., Logan, J. B., and McLaughlin, B. E.: Cross-shore velocity shear, eddies and heterogeneity in water column properties over fringing coral reefs: West Maui, Hawaii, Cont. Shelf. Res., 26, 401-421, 2006.

Strong, A. L., Kroeker, K. J., Teneva, L. T., Mease, L. A., and Kelly, R. P.: Ocean Acidification 2.0: Managing our Changing Coastal Ocean Chemistry, Bioscience, 64, 581-592, https://doi.org/10.1093/biosci/biu072, 2014.

Sunda, W. G. and Cai, W.-J.: Eutrophication induced $\mathrm{CO}_{2-}$ acidification of subsurface coastal waters: interactive effects of temperature, salinity, and atmospheric $p \mathrm{CO}_{2}$, Environ. Sci. Technol., 46, 10651-10659, https://doi.org/10.1021/es300626f, 2012.

Suzuki, A. and Kawahata, H.: Carbon budget of coral reef systems: an overview of observations in fringing reefs, barrier reefs and atolls in the Indo-Pacific regions, Tellus B, 55, 428-444, https://doi.org/10.1034/j.1600-0889.2003.01442.x, 2003.

Swarzenski, P., Dulai, H., Kroeger, K., Smith, C., Dimova, N., Storlazzi, C., Prouty, N., Gingerich, S., and Glenn, C.: Observations of nearshore groundwater discharge: Kahekili Beach Park submarine springs, Maui, Hawaii, J. Hydrol.: Regional Studies, 11, 147-165, https://doi.org/10.1016/j.ejrh.2015.12.056, 2016.

Swarzenski, P. W., Storlazzi, C. D., Presto, M. K., Gibbs, A. E., Smith, C. G., Dimova, N. T., Dailer, M. L., and Logan, J. B.: Nearshore morphology, benthic structure, hydrodynamics, and coastal groundwater discharge near Kahekili Beach Park, Maui, Hawaii, U.S. Geological Survey Open-File Report 2012-1166, 2012. 
Swarzenski, P. W., Dulaiova, H., Dailer, M. L., Glenn, C. R., Smith, C. G., and Storlazzi, C. D.: A geochemical and geophysical assessment of coastal groundwater discharge at select sites in Maui and O'ahu, Hawai'i, in: Groundwater in the Coastal Zones of Asia-Pacific, edited by: Wetzelhuetter, C., Coastal Research Library, Springer Netherlands, 27-46, 2013.

Szmant, A. and Gassman, N. J.: The effects of prolonged "bleaching" on the tissue biomass and reproduction of the reef coral Montastrea annularis, Coral Reefs, 8, 217-224, 1990.

Wiltse, W.: Algal Blooms: Progress Report on Scientific Research, West Maui Watershed Management Project, 1996.

Wooldridge, S. A.: Excess seawater nutrients, enlarged algal symbiont densities and bleaching sensitive reef locations: 1. Identifying thresholds of concern for the Great Barrier Reef, Australia, Mar. Pollut. Bull., https://doi.org/10.1016/j.marpolbul.2016.04.054, online first, 2016.

Yao, W. and Byrne, R. H.: Simplified seawater alkalinity analysis: use of linear array spectrometers, Deep-Sea Res. Pt. I, 45, 13831392, 1998.
Yates, K. K., Rogers, C. S., Herlan, J. J., Brooks, G. R., Smiley, N. A., and Larson, R. A.: Diverse coral communities in mangrove habitats suggest a novel refuge from climate change, Biogeosciences, 11, 4321-4337, https://doi.org/10.5194/bg-114321-2014, 2014.

Yates, K. K., Zawada, D. G., Smiley, N. A., and TilingRange, G.: Divergence of seafloor elevation and sea level rise in coral reef ecosystems, Biogeosciences, 14, 1739-1772, https://doi.org/10.5194/bg-14-1739-2017, 2017.

Zeebe, R. E. and Wolf-Gladrow, D. A.: $\mathrm{CO}_{2}$ in seawater: equilibrium, kinetics, isotopes, Gulf Professional Publishing, 2001.

Zhang, H. and Byrne, R. H.: Spectrophotometric $\mathrm{pH}$ measurements of surface seawater at in-situ conditions: absorbance and protonation behavior of thymol blue, Mar. Chem., 52, 17-25, https://doi.org/10.1016/0304-4203(95)00076-3, 1996. 